\title{
Leaching of Atrazine, Ametryne and Prometryne in the Soil
}

\author{
L. C. Liu and H. R. Cibes-Viadé
}

\section{INTRODUCTION}

The effectiveness of soil-applied herbicides depends to a great extent on their leaching as well as on their capacity to persist in the soil. Many herbicides will remain active for an undeterminate period of time in the top 1 or 2 inches of soil where the weed germinating zone is located. Others will penetrate readily into deeper layers of the soil. The former group of chemicals are selective in nature causing little or no damage to crops at rates of application used in commercial practice. The chemicals included in the latter group are commonly injurious to cultivated plants and thus are used for eradicating deep-rooted, perennial plants.

It is recognized that the depth to which a soil-applied herbicide will move in the soil is related directly to the initial rate of application, to the initial and subsequent soil moisture content, and to the percent clay and organic matter content of the soil. The solubility in water of such herbicides also influences the depth in the soil to which they penetrate: the higher the degree of solubility in water the more rapid the penetration.

It rains rather heavily in Puerto Rico from May to November inclusive and less during the rest of the year. The greatest amount of rain falls along the higher peaks and the northern and eastern sides of the central mountain range. The least amount of rain falls on the southern side of the Island. Under rainfall conditions such as these the loss of soil-applied herbicides to leaching may be of cardinal importance in most of the agricultural land of Puerto Rico. The degree to which an herbicide moves in the soil will determine whether or not it will remain effective for a prolonged period of time.

The only investigation of this nature conducted thus far in Puerto Rico was undertaken sometime ago at the Federal Experiment Station at Mayagüez where studies were made to determine the leaching of 3-(pchlorophenyl)-1-dimethyl urea, (Monuron), ( 8$)^{2}$ sodium, and diethanolamine salts of 2,4-dichlorophenoxy acetic acid and trichloroacetic acid (9).

1 Assistant Plant Physiologist and Plant Physiologist, respectively, Agricultural Experiment Station, Mayagüez Campus, University of Puerto Rico, Rio Piedras, P. R. Thanks are due to Mr. J. Juárez Jr., Soil Scientist, Agricultural Experiment Station, University of Puerto Rico, for his help in identifying and collecting soil samples used in this study and to Mr. Alfonso Riera, Chemist in charge, Central Analytical Laboratory, Agricultural Experiment Station, University of Puerto Rico, for performing the chemical aspects of soil analyses.

Italic numbers in parentheses refer to Literature Cited, p. 18. 
To date, however, there is no information on leaching characteristics of our most important herbicides, namely: 2-chloro-4-ethylamino-6-isopropylamino-s-triazine (Atrazine), 2-methyl mercapto-4-isopropylamino-6-isopropylamino-s-triazine (Ametryne), and 2-methyl mercapto-4-6-isopropylamino-s-triazine (Prometryne). The present study, therefore, was initiated to determine the extent of downward movement of these herbicides under variable amounts of simulated rainfall in various Puerto Rican soils.

\section{REVIEW OF LITERATURE}

Numerous studies on the leaching of triazine herbicides have been reported in the United States and elsewhere. Montgomery and Freed (10) using $\mathrm{C}^{14}$ labeled Simazine and Atrazine found the former remained in the 0- to 1-inch layer of a Chehallis sandy loam soil after application of 12 inches of water. Under the same water treatment, however, the latter chemical penetrated to a depth of 7 to 8 inches. Ashton (1) studied the movement of Simazine, Atratone and Atrazine in three soils with simulated furrow irrigation. He found these chemicals did not move beyond the first inch of the soil layer in phytotoxic concentrations. The extent of lateral movement of the above mentioned herbicides in the three selected soil types was in the order of their solubilities in water, that is, Atratone > Atrazine > Simazine.

The leaching properties of Simazine, Atrazine, Atratone, and Ipazine were investigated by Rodgers (12). He found Atrazine to be the most readily leached in sandy soils. Ipazine was the least, while Simazine and Atratone were intermediate in that respect. Little or no leaching of any of the above-mentioned herbicides was observed below the top 1-inch horizon in a muck soil.

The same author recently (13) reported the leaching of seven s-triazines in lakeland fine sandy soil under greenhouse and field conditions. He found leaching of Atratone to be greatest, followed in decreasing order by Propazine, Atrazine, Simazine, Ipazine, Ametryne, and Prometryne. In a study comparing the downward movement of Simazine and Monuron, Sheets $(15)$ found that both herbicides were displaced by percolating water through soil columns at about the same rate. There was a greater downward movement of Monuron and Simazine in sandy than in clay soil.

Burnside et al. (2), after percolating Simazine through Waukegan silty loam soil, indicated that leaching of Simazine was not greatly increased with the amount of water applied. This same investigator and coworkers (3), in a subsequent investigation, found that leaching of Atrazine was considerably greater than that of Simazine and Monuron in three Nebraska soils. Other leaching studies $(6,14)$, in which either Atrazine or Prometryne were included, showed that Atrazine had greater mobility in the soil than 
Prometryne. These results were confirmed by Harris $(b)$ in an investigation designed to determine the relative movement of Monuron and s-triazine herbicides in the soil through the subirrigation method.

The literature indicates that a number of studies have been conducted concerning the leaching of some of the triazine herbicides.

Most of these leaching studies, however, were conducted with one or a limited number of soil types. More importantly, soil types used in leaching studies in the United States are not of the same origin as those of Puerto Rico. Thus, results reported elsewhere may not be completely applicable to conditions in Puerto Rico.

Table 1.-The physical and chemical properties of soils used in leaching study

\begin{tabular}{|c|c|c|c|c|c|c|c|c|c|c|}
\hline \multirow[b]{2}{*}{ Soil type } & \multirow[b]{2}{*}{$\begin{array}{l}\text { Organic } \\
\text { matter }\end{array}$} & \multirow[b]{2}{*}{$\begin{array}{c}\text { Cation } \\
\text { ex- } \\
\text { change } \\
\text { capac- } \\
\text { ity }\end{array}$} & \multicolumn{3}{|c|}{ Exchange bases } & \multirow[b]{2}{*}{$\begin{array}{c}\text { Soluble } \\
\text { phos- } \\
\text { phorus }\end{array}$} & \multirow[b]{2}{*}{ pH } & \multicolumn{3}{|c|}{ Terture } \\
\hline & & & $\mathrm{Ca}$ & $\mathbf{M g}$ & $\mathbf{K}$ & & & $\begin{array}{c}\text { Sand } \\
(2-0.05 \\
\text { mm.) }\end{array}$ & $\begin{array}{c}\text { Silt } \\
(0.05- \\
0.002 \\
\text { mm.) }\end{array}$ & $\begin{array}{c}\text { Clay } \\
(0.002 \\
\text { mm.) }\end{array}$ \\
\hline & Percent & $\begin{array}{l}\text { Mreq. } \\
100 \mathrm{~g} .\end{array}$ & $\begin{array}{l}\text { Meg. } \\
100 \mathrm{~g} .\end{array}$ & $\begin{array}{l}\text { Meq. } \\
100 \mathrm{~g} .\end{array}$ & $\begin{array}{l}\text { Meq./ } \\
100 \mathrm{~g} .\end{array}$ & P.p.m. & & Percent & Percent & Percent \\
\hline Aguadilla & 2.5 & 10 & 17.1 & 3.3 & 0.20 & 17 & 7.4 & 74.4 & 19.5 & 6.1 \\
\hline Fraternidad & 4.2 & 58 & 27.6 & 19.0 & 0.65 & 33 & 5.9 & 11.1 & 23.8 & 65.1 \\
\hline Mabi & 4.9 & 31 & 11.5 & 14.2 & 0.56 & 4 & 5.5 & 23.4 & 40.6 & 36.0 \\
\hline Tos & 2.0 & 13 & 6.9 & 1.5 & 0.23 & 2 & 5.3 & 41.5 & 38.3 & 20.2 \\
\hline
\end{tabular}

\section{MATERIALS AND METHODS}

Samples of Aguadilla, Fraternidad, Mabí, and Toa soil types were collected from different locations in Puerto Rico. These were brought into the greenhouse in large galvanized iron containers. After being air-dried, pulverized, and thoroughly screened the samples were stored for the leaching studies. Both physical as well as chemical properties of said soils were determined by methods essentially the same as those employed in previous experiments (7). The resulting data is listed in table 1.

Soil leaching columns, 3 inches in diameter and 15 inches in height were prepared by staking five 2 -inch plastic sections topped by five 1 -inch ones. The various sections were held together with 1-inch waterproof masking tape. The bottom end of the columns were covered with folded cheesecloth fastened by means of rubber bands. When the columns were prepared, they were filled with the individual types of soils. The top 1-inch section of each column was left unfilled to leave room for the application of the variable amounts of simulated rainfall. The columns subsequently were placed on a specially designed leaching rack with provision for free draining of water. Before the differential treatments were initiated, the columns were brought 
to field capacity and left to drain for a 2-day period. Commercial $80 \mathrm{~W}$ formulation of Atrazine, Ametryne and Prometryne were applied uniformly with a pipette over the surface of the soil at rates of 0,4 , and 20 lb./A in $10 \mathrm{ml}$. aqueous suspension. Prior to the application of the various water increments, a piece of glass wool was placed on the surface of the soil columns to avoid puddling of the soil. The columns were leached, soon after, with $116,232,464$, and $928 \mathrm{ml}$. of water, respectively, equivalent to 2,4 , and 8 inches of simulated rainfall.

The amount of water equivalent to 1-inch of simulated rainfall was calculated on the basis of a 1-inch plastic tubing section, according to the formula $V=\pi \mathrm{r}^{2} h$, where $V=$ volume in cubic centimeters, $\pi=3.1416$, $r=3.81 \mathrm{~cm}$. and $h=2.54 \mathrm{~cm}$. The amount of water thus calculated was added to the soil columns at the rate of 0.25 inch. The infiltration of this much water varied markedly with the soil type, ranging from 30 minutes for the Aguadilla soil to 90 minutes for the Fraternidad soil. Because of these differences it took $2,3,4$, and 8 successive workdays to complete the leaching process for Aguadilla, Toa, Mabi, and Fraternidad soils respectively. Two days after the leaching process was completed, the soil columns were separated into their various sections by slicing through the joints with a sharp knife. The soil from each section was transferred to a 5-ounce aluminum foil custard container for bioassay. In the case of the 2-inch sections, the soil samples were divided in half to fit the containers.

Kanota oat (Avena sativa L.) was adopted as the indicator plant for bioassaying the relative concentration of the various herbicides at different soil depths. Thirteen oat seeds were planted in each container. The seeded containers were set in a greenhouse bench where they remained for a period of 4 weeks. At the end of the 4-week period, 10 of the 13 oat plants were cut at the soil surface and the fresh weight determined for each culture. The fresh weight of the aerial part of oat plants grown in the herbicide treated soil, in relation to the weight of plants grown in untreated soil, was taken as a measure of herbicide toxicity. The highest concentration of each herbicide was assumed to be in the column section with the least fresh weight of plants, i.e. the lowest value expressed as percent of the untreated. Finally, an analysis was made for variance and least significant difference using the method of Dubey and Freeman (4). All treatments were run in triplicate. Due to the great number of treatments involved, however, the leaching and bioassay work included only one soil type at a time.

\section{RESULTS AND DISCUSSION}

The leaching of Atrazine, Ametryne and Prometryne, as indicated by the fresh weight of oat plants and expressed as percent of the untreated or 
checks, was found to be most pronounced in the Aguadilla soil (table 2). This light textured soil, with its corresponding low organic matter content and cation exchange capacity, apparently has a very low adsorptive capacity for the above herbicides thus facilitating their free movement in the soil. At the commercial rate of $4 \mathrm{lb}$./A leached with 1-inch of water, Atrazine moved to the 2-3 inch section depth. Ametryne and Prometryne, however, penetrated very little, remaining in the 1-2 and 0-1 inch sections respectively. The downward movement of the three herbicides increased further by only raising the amount of percolating water. For instance, Atrazine, at the stated $4 \mathrm{lb}$./A leached with 8 inches of simulated rainfall, was carried to the 6-8 inch section. On the other hand, Ametryne was displaced into the 2-3 inch section while Prometryne remained in the 1-2 inch zone of the soil column. Increasing the rate of application from $4 \mathrm{lb}$. to $20 \mathrm{lb}$./A also influenced the relative leaching of the above herbicides in this particular soil. In fact, Atrazine at the maximum rate of $20 \mathrm{lb} . / \mathrm{A}$ leached with the 1-inch water increment moved about two inches deeper than at $4 \mathrm{lb}$./A. Ametryne and Prometryne under similar conditions penetrated only an additional inch. Leaching the soil columns with the 8inch water treatment caused Atrazine to leach to the 10-12 inch section. The two other triazine herbicides leached only half that distance with the same water increment.

In the Fraternidad soil the extent of the downward movement of all three chemicals was not as marked as in the above soils. At $4 \mathrm{lb}$./A, leached with the lower amount of water, Atrazine was not able to penetrate further than the 1-2 inch section. Similarly, neither Ametryne nor Prometryne could be detected in phytotoxic concentrations below the first inch layer of soil (table 3). Increasing the amount of water from the 1-inch to the 8inch level augmented the penetration of Atrazine somewhat (4-6 inch section). The effect of this water treatment upon the other two triazine compounds was negligible. At the higher doses of $20 \mathrm{lb}$./A and 1-inch water increment Atrazine was carried down by the water stream to a depth of 2-3 inches, while Ametryne as well as Prometryne remained more or less static. The deepest penetration achieved by any of the above herbicides was attained under the combined effects of the higher chemical dose and water increment. Accordingly, Atrazine was dispersed right into the 6-8 section while both Ametryne and Prometryne were found to be phytotoxic at a 3-4 inch depth.

All three herbicides exhibited very little mobility in either the Mabi or Toa soils. None of them penetrated to any appreciable extent when applied at the rate of $4 \mathrm{lb}$./A and leached with 1-inch of simulated rainfall. However, at the higher herbicide and water treatments Atrazine was washed down to the 6-8 inch section in both soils (Tables 4 and 5). Ametryne and Prome- 
TABLE 2.-Leaching of Atrazine, Ametryne, and Prometryne as indicated by relative fresh weight of oats grown in Aguadilla soil collected from various depths of the soil column

\begin{tabular}{|c|c|c|c|c|c|}
\hline \multirow{2}{*}{ Herbicide and rate } & \multirow{2}{*}{$\begin{array}{l}\text { Soil column } \\
\text { section }\end{array}$} & \multicolumn{4}{|c|}{$\begin{array}{l}\text { Fresh weight aats as percent of untreated (inches } \\
\text { of simulated water leached through) }\end{array}$} \\
\hline & & 1 & 2 & 4 & 8 \\
\hline Atrazine 4.lb./A & $\begin{array}{c}\text { Inches } \\
0-1 \\
1-2 \\
2-3 \\
3-4 \\
4-6 \\
6-8 \\
8-10 \\
10-12 \\
12-14 \\
\text { LSD 5\% }\end{array}$ & $\begin{array}{r}0 \\
0 \\
18 \\
95 \\
82 \\
88 \\
79 \\
89 \\
78 \\
19\end{array}$ & $\begin{array}{r}0 \\
0 \\
0 \\
14 \\
57 \\
80 \\
96 \\
105 \\
104 \\
31\end{array}$ & $\begin{array}{r}0 \\
0 \\
0 \\
0 \\
11 \\
84 \\
95 \\
116 \\
131 \\
21\end{array}$ & $\begin{array}{r}0 \\
0 \\
0 \\
0 \\
0 \\
1 \\
87 \\
125 \\
130 \\
25\end{array}$ \\
\hline Ametryne 4 lb./A & $\begin{array}{c}0-1 \\
1-2 \\
2-3 \\
3-4 \\
4-6 \\
6-8 \\
8-10 \\
10-12 \\
12-14 \\
\text { LSD } 5 \%\end{array}$ & $\begin{array}{r}0 \\
57 \\
90 \\
98 \\
100 \\
88 \\
81 \\
98 \\
88 \\
23\end{array}$ & $\begin{array}{r}0 \\
36 \\
74 \\
89 \\
99 \\
82 \\
88 \\
100 \\
100 \\
23\end{array}$ & $\begin{array}{r}0 \\
29 \\
89 \\
98 \\
100 \\
91 \\
105 \\
113 \\
118 \\
31\end{array}$ & $\begin{array}{r}0 \\
0 \\
58 \\
91 \\
103 \\
123 \\
142 \\
133 \\
126 \\
33\end{array}$ \\
\hline Prometryne $4 \mathrm{lb} . / \mathrm{A}$ & $\begin{array}{c}0-1 \\
1-2 \\
2-3 \\
3-4 \\
4-6 \\
6-8 \\
8-10 \\
10-12 \\
12-14 \\
\text { LSD } 5 \%\end{array}$ & $\begin{array}{r}0 \\
88 \\
91 \\
90 \\
99 \\
99 \\
89 \\
98 \\
92 \\
23\end{array}$ & $\begin{array}{l}0 \\
87 \\
88 \\
95 \\
97 \\
86 \\
96 \\
99 \\
93 \\
60\end{array}$ & $\begin{array}{r}0 \\
65 \\
78 \\
92 \\
93 \\
88 \\
96 \\
106 \\
106 \\
50\end{array}$ & $\begin{array}{r}0 \\
33 \\
99 \\
110 \\
116 \\
118 \\
142 \\
114 \\
127 \\
31\end{array}$ \\
\hline Atrazine $20 \mathrm{lb} . / \mathrm{A}$ & $\begin{array}{c}0-1 \\
1-2 \\
2-3 \\
3-4 \\
4-6 \\
6-8 \\
8-10 \\
10-12 \\
12-14 \\
\text { LSD 5\% }\end{array}$ & $\begin{array}{r}0 \\
0 \\
0 \\
0 \\
71 \\
94 \\
91 \\
93 \\
88 \\
34\end{array}$ & $\begin{array}{r}0 \\
0 \\
0 \\
0 \\
43 \\
45 \\
81 \\
92 \\
94 \\
23\end{array}$ & $\begin{array}{r}0 \\
0 \\
0 \\
0 \\
0 \\
33 \\
97 \\
108 \\
117 \\
28\end{array}$ & $\begin{array}{r}0 \\
0 \\
0 \\
0 \\
0 \\
0 \\
0 \\
55 \\
114 \\
22\end{array}$ \\
\hline
\end{tabular}


TABLe 2-Continued

\begin{tabular}{|c|c|c|c|c|c|}
\hline \multirow{2}{*}{ Herbicide and rate } & \multirow{2}{*}{$\begin{array}{l}\text { Soil column } \\
\text { section }\end{array}$} & \multicolumn{4}{|c|}{$\begin{array}{l}\text { Fresh weight oats as percent of untreated (inches } \\
\text { of simulated water leached through) }\end{array}$} \\
\hline & & 1 & 2 & 4 & 8 \\
\hline Ametryne 20 lb./A & $\begin{array}{c}\text { Inches } \\
0-1 \\
1-2 \\
2-3 \\
3-4 \\
4-6 \\
6-8 \\
8-10 \\
10-12 \\
12-14 \\
\text { LSD 5\% }\end{array}$ & $\begin{array}{r}0 \\
0 \\
30 \\
72 \\
95 \\
95 \\
92 \\
108 \\
101 \\
27\end{array}$ & $\begin{array}{r}0 \\
0 \\
0 \\
24 \\
94 \\
85 \\
88 \\
106 \\
96 \\
22\end{array}$ & $\begin{array}{r}0 \\
0 \\
0 \\
0 \\
28 \\
104 \\
120 \\
128 \\
146 \\
43\end{array}$ & $\begin{array}{r}0 \\
0 \\
0 \\
0 \\
41 \\
64 \\
111 \\
111 \\
109 \\
43\end{array}$ \\
\hline Prometryne $20 \mathrm{lb} . / \mathrm{A}$ & $\begin{array}{c}0-1 \\
1-2 \\
2-3 \\
3-4 \\
4-6 \\
6-8 \\
8-10 \\
10-12 \\
12-14 \\
\text { LSD 5\% }\end{array}$ & $\begin{array}{r}0 \\
0 \\
66 \\
93 \\
93 \\
96 \\
82 \\
101 \\
100 \\
14\end{array}$ & $\begin{array}{r}0 \\
0 \\
4 \\
75 \\
99 \\
86 \\
93 \\
83 \\
91 \\
21\end{array}$ & $\begin{array}{r}0 \\
0 \\
1 \\
17 \\
91 \\
116 \\
128 \\
148 \\
146 \\
29\end{array}$ & $\begin{array}{r}0 \\
0 \\
4 \\
3 \\
49 \\
89 \\
135 \\
136 \\
122 \\
35\end{array}$ \\
\hline
\end{tabular}

tryne, on the other hand, moved very little under similar circumstances. Obviously, considerable difference seems to exist between the mobility of Atrazine and the other two triazine compounds in the Mabi and Toa soils. This difference may be easily explained on the basis of the high organic matter and clay content of the Mabi soil. Apparently, Ametryne and Prometryne are more readily fixed in the soil under such conditions than Atrazine, rendering them less subject to leaching. However, this explanation does not hold in the case of the Toa soil. Organic matter and clay content of Toa soil is not particularly high, as shown in Table 1.

Our experiments show the ready mobility of Atrazine in the soil, as noted by other investigators $(8,5,6,10,12,13)$. In accordance, also, with the findings of other workers, is the fact that Prometryne moves very little $(12,13,14)$. Our experiments demonstrated that Ametryne leaches slightly more than Prometryne under greenhouse conditions and this is in close agreement with the result noted by Rodgers (13) under actual field conditions.

As stated previously, the degree in which a herbicide may be leached in 
TaBuE 3.-Leaching of Atrazine, Ametryne, and Prometryne as indicated by relative fresh weight of oals grown in Fraternidad soil collected from various depths of the soil column

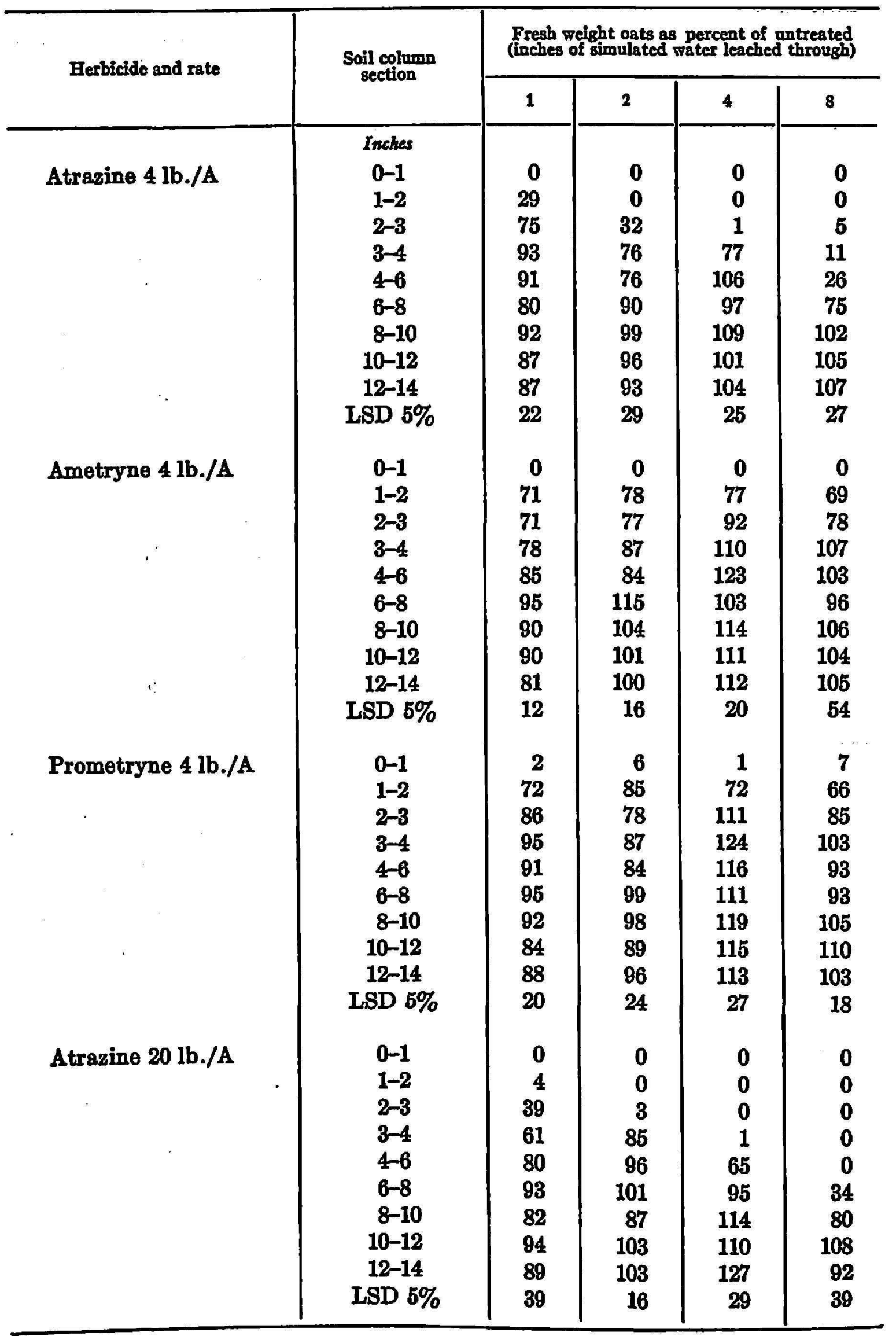


Tabue 3.-Continued

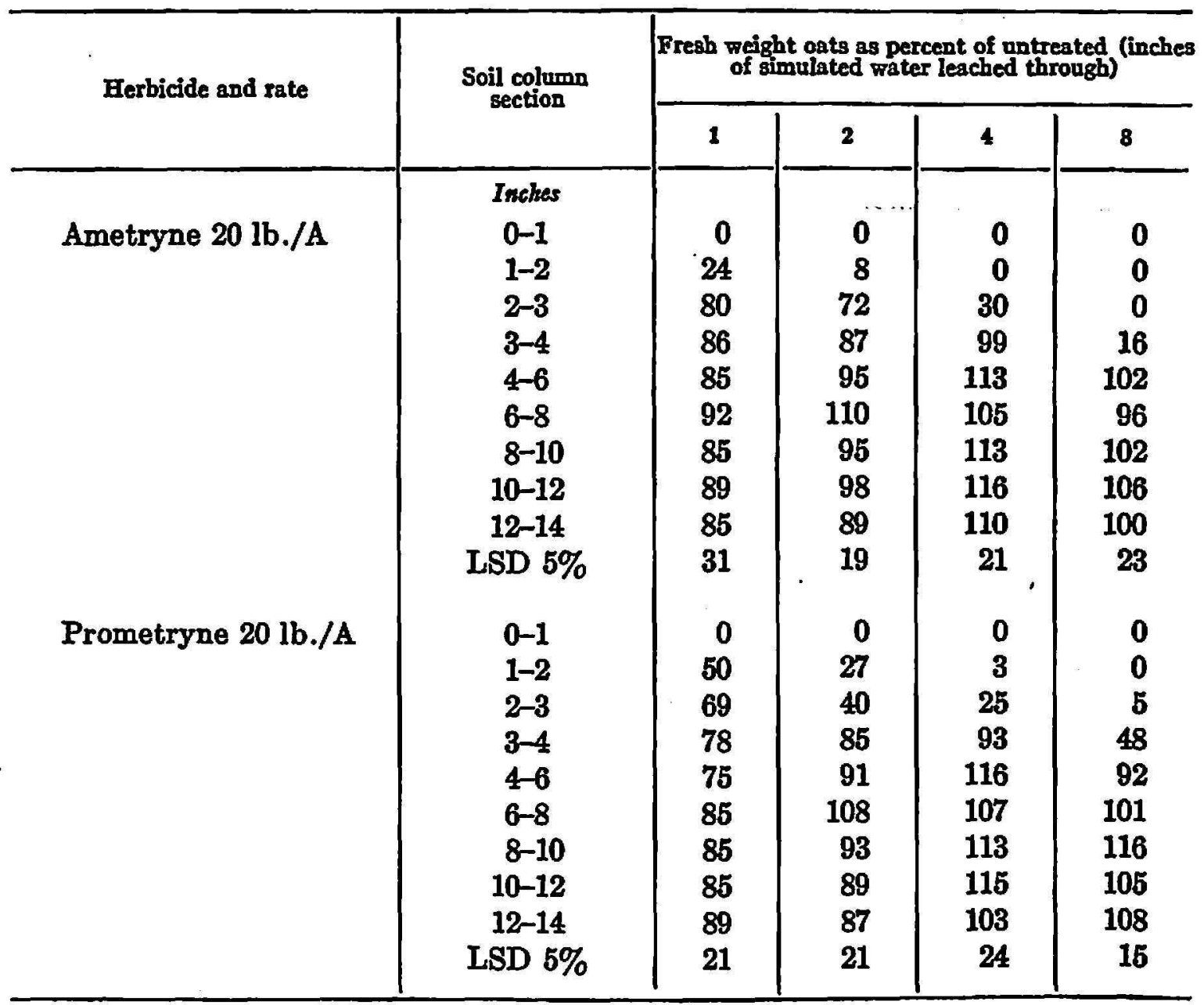

the soil is related directly to its solubility in water. However, the results obtained in the present study were not in complete agreement with this statement. Seemingly the adsorption of the herbicides by the soil colloids and organic matter, rather than their solubility in water, was mostly responsible for the differential leaching. Thus, the low soil adsorption of Atrazine and high adsorption of Prometryne, as found by Harris (E) and Talbert (16), may account for the deeper penetration of the former in comparison to that of the latter.

The difference in the leaching tendency demonstrated by these three herbicides may warrant the conclusion that Ametryne or Prometryne applied in commercial doses in regions of high rainfall may be safer to use than Atrazine. Experiments conducted at this Station on use of herbicides for control of weeds in plantains (Musa paradisiaca $L_{\text {. }}$ ) and other root crops have shown that Atrazine may be toxic to these crops under certain conditions. Conversely, the other two chemicals were not toxic to the crops mentioned even at high rates. The injury caused to plantains by Atrazine could be attributed mainly to its relatively high penetrativity in the soil. 
14 JOURNAL OF AGRICULTURE OF UNIVERSITY OF PUERTO RICO

TABLE 4.-Leaching of Atrazine, Ametryne, and Prometryne as indicated by fresh weight of oats grown in Mabi soil collected from various depths of the soil column

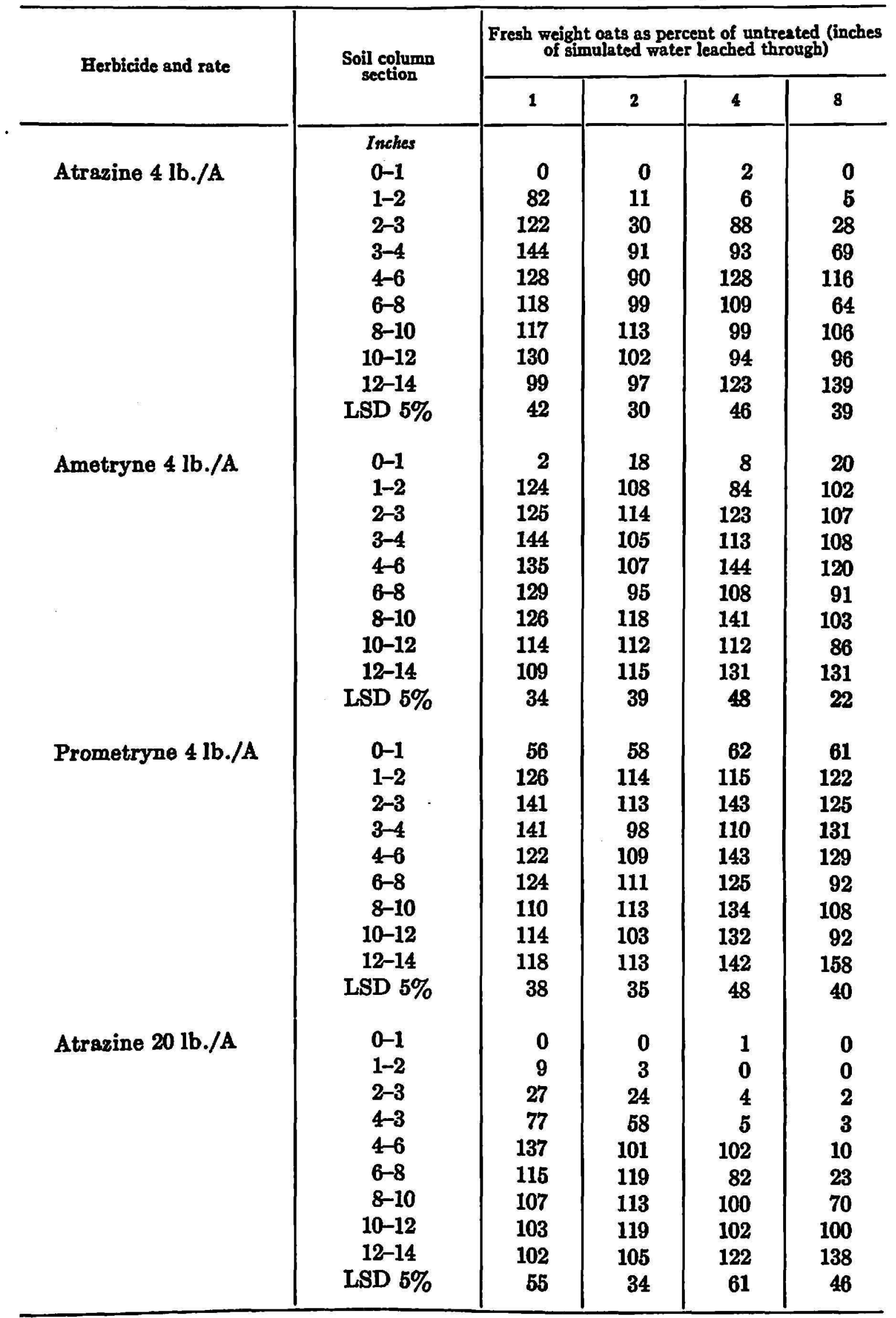


TABLE 4.-Continued

\begin{tabular}{|c|c|c|c|c|c|}
\hline \multirow{2}{*}{ Herbicide and rate } & \multirow{2}{*}{$\begin{array}{l}\text { Soil column } \\
\text { section }\end{array}$} & \multicolumn{4}{|c|}{$\begin{array}{l}\text { Fresh weight oats as percent of untreated (inches } \\
\text { of gimulated water leached through) }\end{array}$} \\
\hline & & 1 & 2 & 4 & 8 \\
\hline \multirow{10}{*}{ Ametryne $20 \mathrm{lb} . / \mathrm{A}$} & Inches & & & & \\
\hline & $\begin{array}{l}0-1 \\
1-2\end{array}$ & $\begin{array}{r}0 \\
94\end{array}$ & $\begin{array}{r}0 \\
106\end{array}$ & $\begin{array}{r}1 \\
50\end{array}$ & $\begin{array}{r}0 \\
28\end{array}$ \\
\hline & $2-3$ & 111 & 116 & 131 & 96 \\
\hline & $3-4$ & 127 & 107 & 110 & 117 \\
\hline & $4-6$ & 123 & 112 & 160 & 129 \\
\hline & $6-8$ & 119 & 122 & 106 & 112 \\
\hline & $8-10$ & 113 & 126 & 115 & 127 \\
\hline & $10-12$ & 97 & 110 & 107 & 96 \\
\hline & $12-14$ & 94 & 119 & 132 & 148 \\
\hline & LSD $5 \%$ & 32 & 25 & 57 & 43 \\
\hline \multirow[t]{10}{*}{ Prometryne $20 \mathrm{lb} . / \mathrm{A}$} & $0-1$ & 15 & 6 & 14 & 29 \\
\hline & $1-2$ & 116 & 112 & 114 & 91 \\
\hline & $2-3$ & 98 & 137 & 127 & 108 \\
\hline & $3-4$ & 116 & 115 & 108 & 123 \\
\hline & $4-6$ & 142 & 106 & 119 & 136 \\
\hline & $6-8$ & 122 & 118 & 97 & 136 \\
\hline & $8-10$ & 120 & 128 & 124 & 125 \\
\hline & $10-12$ & 122 & 111 & 96 & 110 \\
\hline & $12-14$ & 114 & 112 & 121 & 169 \\
\hline & LSD $5 \%$ & 37 & 41 & 44 & 45 \\
\hline
\end{tabular}

On the other hand, sugarcane has been found highly tolerant to triazine herbicides. This is due, however, to a self-detoxifying mechanism which converts triazine herbicides into hydroxytriazines. The shorter persistence of Atrazine under field conditions in Puerto Rico also may be explained on the basis of its greater penetrativity, which lessens the concentration.

\section{SUMMARY}

An experiment was conducted during 1967 to study leaching characteristics of the herbicides Atrazine, Ametryne, and Prometryne in Aguadilla, Fraternidad, Mabi, and Toa soils. Atrazine, Ametryne and Prometryne were applied at rates of 0,4 , and $20 \mathrm{lb}$./A to soil columns and leached with 1, 2, 4, and 8 inches of simulated rainfall.

Of the triazine chemicals, Atrazine was found to have the greatest downward penetrativity while Prometryne showed the least. The mobility of Ametryne in soil was slightly greater than that of Prometryne. The leaching tendency of Atrazine augmented not only with the increasing rates of herbicides but also with increasing amounts of simulated rainfall. The movement or penetrativity of both Ametryne and Prometryne in the soil 
TabLe 5.-Leaching of Atrazine, Ametryne, and Prometryne as indicated by relative fresh weight of oats grown in Toa soil collected from various depths of the soil column

\begin{tabular}{|c|c|c|c|c|c|}
\hline \multirow{2}{*}{ Herbicide and rate } & \multirow{2}{*}{$\begin{array}{c}\text { Soil column } \\
\text { section }\end{array}$} & \multicolumn{4}{|c|}{$\begin{array}{l}\text { Fresh weight oats as percent of untreated (inches } \\
\text { of simulated water leached tbrough) }\end{array}$} \\
\hline & & 1 & 2 & 4 & 8 \\
\hline \multirow{10}{*}{ Atrazine 4 lb./A } & Inches & & & & \\
\hline & $\begin{array}{l}0-1 \\
1-2\end{array}$ & $\begin{array}{r}0 \\
117\end{array}$ & $\begin{array}{r}0 \\
62\end{array}$ & $\begin{array}{r}0 \\
39\end{array}$ & $\begin{array}{l}0 \\
9\end{array}$ \\
\hline & $2-3$ & 123 & 88 & 69 & 25 \\
\hline & $3-4$ & 120 & 91 & 74 & 61 \\
\hline & $4-6$ & 138 & 92 & 74 & 56 \\
\hline & $6-8$ & 111 & 119 & 104 & 75 \\
\hline & $8-10$ & 125 & 114 & 115 & 110 \\
\hline & 10-12 & 119 & 99 & 106 & 133 \\
\hline & $12-14$ & 98 & 112 & 108 & 105 \\
\hline & LSD 5\% & 21 & 54 & 36 & 31 \\
\hline \multirow[t]{2}{*}{ Ametryne 4 lb./A } & $0-1$ & 11 & 3 & 8 & 4 \\
\hline & $1-2$ & 116 & 87 & 95 & 135 \\
\hline & $2-3$ & 102 & 93 & 98 & 119 \\
\hline & $3-4$ & 104 & 89 & 98 & 119 \\
\hline & $4-6$ & 97 & 80 & 101 & 129 \\
\hline & $6-8$ & 101 & 100 & 120 & 126 \\
\hline : & $8-10$ & 113 & 92 & 87 & 144 \\
\hline . & $10-12$ & 104 & 95 & 98 & 128 \\
\hline & $12-14$ & 102 & 146 & 105 & 119 \\
\hline 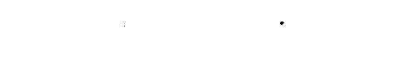 & LSD 6\% & 48 & 44 & 30 & 41 \\
\hline \multirow[t]{3}{*}{ Prometryne 4 lb./A } & $0-1$ & 44 & 49 & 43 & 45 \\
\hline & $1-2$ & 96 & 93 & 101 & 131 \\
\hline & $2-3$ & 98 & 102 & 115 & 118 \\
\hline \multirow{3}{*}{. } & $3-4$ & 95 & 71 & 110 & 105 \\
\hline & $4-6$ & 93 & 80 & 97 & 123 \\
\hline & 6-8 & 86 & 97 & 114 & 119 \\
\hline \multirow{4}{*}{ - } & $8-10$ & 101 & 88 & 99 & 119 \\
\hline & 10-12 & 85 & 83 & 102 & 142 \\
\hline & $12-14$ & 89 & 90 & 109 & 121 \\
\hline & LSD $5 \%$ & NS & NS & 39 & 45 \\
\hline \multirow[t]{10}{*}{ Atrazine $20 \mathrm{lb} . / \mathrm{A}$} & $0-1$ & $\mathbf{0}$ & $\mathbf{0}$ & 5 & 0 \\
\hline & 1-2 & 21 & 6 & 0 & 0 \\
\hline & $2-3$ & 51 & 24 & 2 & 11 \\
\hline & $3-4$ & 51 & 36 & 16 & 15 \\
\hline & $4-6$ & 103 & 42 & 35 & 13 \\
\hline & $6-8$ & 110 & 84 & 68 & 22 \\
\hline & $8-10$ & 128 & 90 & 97 & 81 \\
\hline & $10-12$ & 108 & 95 & 112 & 112 \\
\hline & $\begin{array}{c}12-14 \\
-107\end{array}$ & 107 & 94 & 94 & 118 \\
\hline & LSD 5\% & 33 & 33 & 53 & 43 \\
\hline
\end{tabular}


TABLE 5.-Continued

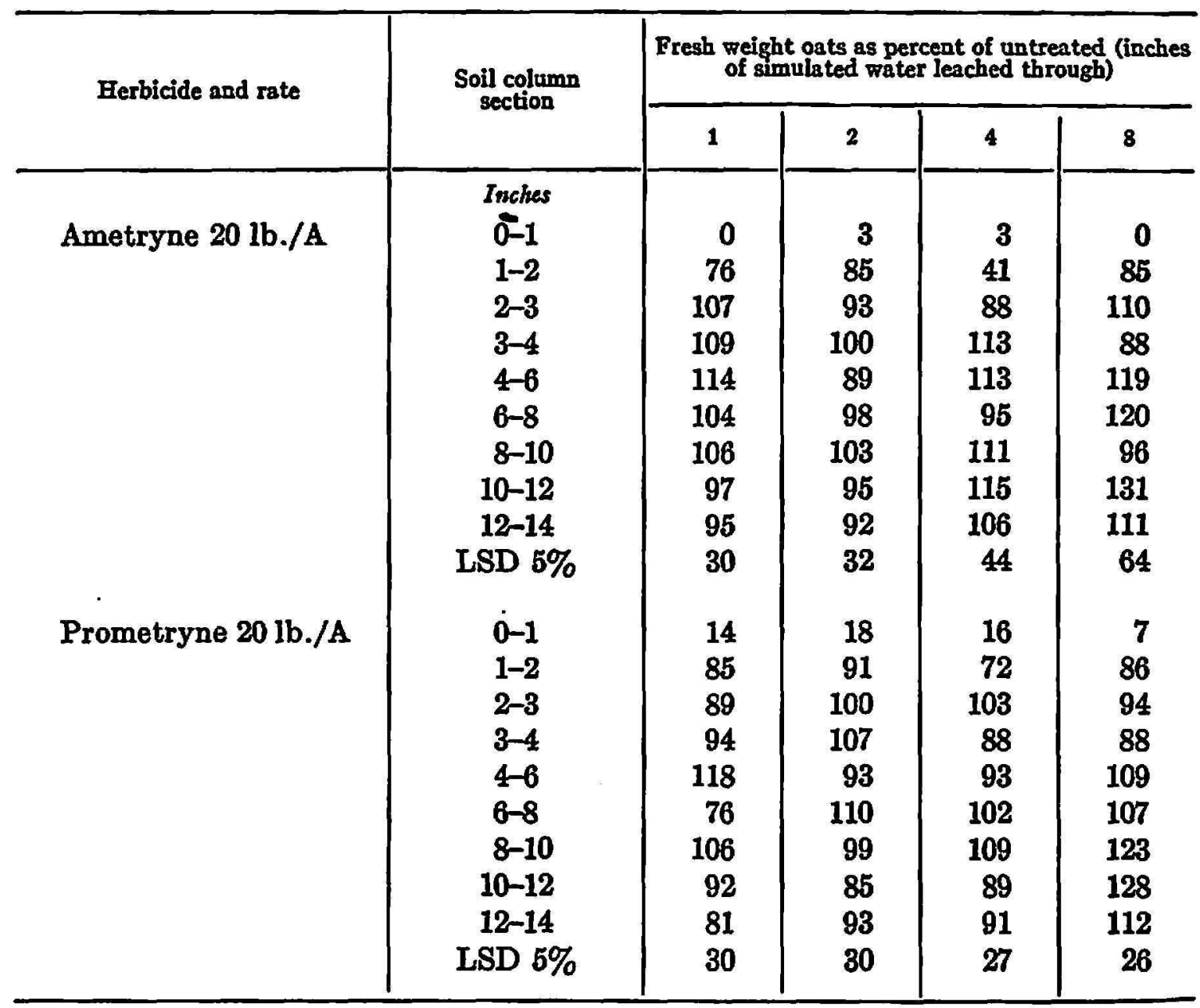

was not exactly a function of either rate of application or amount of water. Leaching of these herbicides was most pronounced in Aguadilla soil and least in Mabí soil.

\section{RESUMEN}

En 1967 se hizo un estudio para determinar la capacidad de filtración de los yerbicidas Atrazine, Ametryne y Prometryne en los suelos Aguadilla, Fraternidad, Mabi y Toa. El Atrazine, el Ametryne y el Prometryne se aplicaron a razón de 0,4 y 20 libras por acre a columnas de tierra y luego fueron lixiviados con $1,2,4$ y 8 pulgadas de lluvia simulada.

Entre las triazinas, el Atrazine demostró la mayor capacidad para penetrar el suelo y el Prometryne la menor. La movilidad del Ametryne fue un poco mayor que la del Prometryne. La tendencia del Atrazine a lixiviarse aumentó no sólo con los niveles de los yerbicidas, sino que también con el aumento de la cantidad de lluvia simulada. El movimiento o capacidad penetrativa en el suelo, tanto del Ametryne como del Prometryne, no fue la función particular de ninguno de los dos factores, a saber, el nivel de las aplicaciones y la cantidad de agua. 
La lixiviación de estos yerbicidas fue más marcada en el suelo Aguadilla y menos en el Mabi.

\section{LITERATURE CITED}

1. Ashton, F. M., Movement of herbicide in soils with simulated furrow irrigation, Weeds 9: 612-19, 1961.

2. Burnside, O. C., Schmidt, E. L., and Behrens, R., Dissipation of Simazine from the soil, Weeds 9: 477-84, 1961.

3. Burnside, O. C., Fenster, C. R., and Wicks, G. A., Dissipation and leaching of Monuron, Simazine and Atrazine in Nebraska soils, Weeds 11: 209-13, 1963.

4. Dubey, H. D., and Freeman, J. F., Leaching of Linuron and Diphenamid in soils, Weeds 18: 360-62, 1965.

5. Harris, C. I., Adsorption, movement and phytotoxicity of Monuron and s-triazine herbicides, Weeds 14: 4-10, 1966.

6. Ivey, M. J., and Andrew, Henry, Leaching of Simazine, Atrazine, Diuron and DCPA in soil columns, Proc. South. Weed Conf. 18: 670-84, 1965.

7. Liu, L. C. and Cibes, H. R., Influence of soil properties on the phytotoxicity of Atrazine, Ametryne, Prometryne, and Diuron in Puerto Rican soils, J. Agr. Univ. P.R. 52(4): 269-80, 1968.

8. Loustalot, A. J., Muzik, T. J., and Cruzado, H. J., A study of the persistence of CMU in soil, Agr. Chem. 8: 52-3, 97-9, 101, 1953.

9. Loustalot, A. J., and Ferrer, R., Studies on the persistence and movement of sodium trichloracetate in the soil, Agron. J. 42: 323-27, 1950.

10. Montgomery, M., and Freed, V. H., A comparison of the leaching behavior of Atrazine and Simazine in Chehallis sandy loam, Res. Rept. West. Weed Conf. 79: 1959.

11. Muzik, T. J., Loustalot, A. J., and Cruzado, H. J., Movement of 2,4-D in soil, Agron. J. 4s: 149-50, 1951.

12. Rodgers, E. G., Leaching of four triazines in three soils as influenced by varying frequencies and rates of simulated rainfall, Proc. South. Weed Conf. 16: 268, 1962.

13. - - Leaching of seven s-triazines, Weeds 16: 117-20, 1868.

14. Shahied Shahiedy and Henry Andrew, Leaching of Trifluralin, Linuron, Prometryne and Cotoran in soil columns, Proc. South. Weed Conf. 19: 522-34, 1966.

15. Sheets, T. J., The comparative toxicities of Monuron and Simazine in soil, Weeds $\gamma:$ 189-94, 1959.

16. Talbert, R. E., and Fletchall, O. H., The adsorption of some s-triazines in soils, Weeds 18: 46-52, 1965. 